\title{
Soil Management Strategies for Radish and Potato Crops: Yield Response and Economical Productivity in the Relation to Organic Fertilizer and Ridging Practice
}

\author{
Masakazu Komatsuzaki ${ }^{1}$ and Lei Dou ${ }^{1,2}$ \\ ${ }^{1}$ College of Agriculture, Ibaraki University, Ibaraki \\ 2Soil and Fertilizer Institute, Shandong \\ ${ }^{1}$ Japan \\ ${ }^{2}$ China
}

\section{Introduction}

Modern conventional agriculture, which is based on heavy use of chemical fertilizers and energy inputs and oriented to maximization of returns and profits, results in soil fertility decrease, ground water pollution, ecological environment unbalance, as often regarded as detrimental and unsustainable when considered from economic, social and environmental perspectives in a long term. Since the beginning of the 21st century, as sustainability awareness spreads, organic farming and organic food have been attracting a lot of attention due to their direct relationships to nutrition and environment, both essential for our future life. In this context, the development of organic farming has showed a strong growth in the world. Organic farming is the process that crops are planted using only natural methods to increase yield and maintain soil fertility. In comparison with conventional agriculture, organic farming could produce healthier agricultural products while conserving the quality of the soil and surrounding environment.

The transition from conventional to organic farming is accompanied by changes in an array of soil chemical and physical properties and processes that affect soil fertility (Jongtae Lee, 2010). Organic management forms the foundation of an healthy and sustainable agricultural system. Organic farming regenerates soil fertility through organic fertilizer and proper farming practices, which could increase the organic matter in the soil. Increased organic matter makes nutrients more available, improves soil structure, raises crop growth, enhances water field capacity and drainage, and decreases soil erosion(Brian Baker et al, 2005).

Organic fertilizer has been alternatively attention since it enhances soil quality, especially adding soil organic matter and ensures activities of soil micro livings. Crops require more than 20 nutrients for growth, and some of these nutrients are obtained primarily from the soil. Organic fertilizer contains significantly high levels of nutrients, and is also high in organic matter content and a variety of micronutrients in general, which may improve the crop yield in the long term. At the same time, the utilization of organic fertilizer helps to 
reduce resource use, because it is usually made of organic by-products, such as oil lees, soybean meal, and fish meal. Organic fertilizer mainly relies on renewable materials rather than on nonrenewable materials and fossil fuels. Organic fertilizer is thus an important material for organic, chemical free agriculture and eco-farming.

The demand of organic agricultural products is increasing rapidly since modern agriculture has been said to be degrading environmental quality and food safety. In 1999, the JAS law defined the organic agricultural products that must be certified by an organic certification group. This has led to a greater demand for organic products. Today, the amount of current organic agricultural products lags behind consumer demand. However, the amount of chemical free agricultural products has been increasing because they are easier to grow than organic products. The demand is especially high for processed foods, such as potato chips, yellow radish pickled, and so on.

One of the major problems impeding the use of organic fertilizer is that it is usually more expensive than chemical fertilizer. However, if organic fertilizer can increase the crop yields over the long term by enhancing soil quality, rising costs for using organic fertilizer may be offset by increasing yields. However, the yield produced by organic fertilizer would differ depending on the crop, soil, and climatic conditions.

Potatoes and radish require a high level of soil fertility and these are important crops in the rotation in Japan. Recently, traditional composting practice that called Bocashi are becoming widely spread in Asian countries. One of the major advantages of using Bocashi is enhancing the recycle of agricultural by-products, and reduces the costs for keeping nutrient in the soil. However, the information regarding yield response and qualities of potato using Bocashi are limited. For potato production, ridging practice affects the yield response and economical productivities (Carter et al. 2005), and ridging practice may affects the decompose speed of organic fertilizer due to the difference of soil temperature in the ridges.

The objectives of this research were to determine the yield response of using organic fertilizer, manure, and effective microbial materials for radish and potato cultures. These results would be useful for making cost analyses between organic and chemical fertilizer application.

\section{Materials and methods}

\subsection{Yield response between chemical and organic fertilizer for radish and potato culture from 1994 through 1997}

\subsubsection{Field and experimental design}

The research of radish was conducted at the experimental farm of Ibaraki University (latitude $36^{\circ} 1^{\prime} 48^{\prime \prime} \mathrm{N}$, longitude 140 12'40"E) in Humic Allophane soils (Hapluduat, Haplic Andosols) from 1994 through 1997. The three fertilizer application systems (chemical, organic, and organic with microbial materials), with cow manure application represented the split factors. The fertilizer and manure application systems were shown in Table 1.

The organic fertilizer contained soybean and rapeseed meal, fish meal, bone and brood meal (Source from Iseki Kanto, Co. Ltd.). Microbial materials is the meat meal, rice bran, wheat bran, and microorganism included bacteria (Azotomonas, Bacillus, Pseudomonas, Clostridium, 
Rhizobium and Bacterium), yeast (Saccharomyces, Candida, Endomycopis, and Cladosporium), actinomyces (Nocardia and Streptomyces), and a filamentous fungus (Aspergillus) (Source from Iseki Kanto, Co. Ltd.). Total nitrogen and carbon of these organic materials were shown in table 2.

\begin{tabular}{|c|c|c|c|c|c|c|c|c|c|}
\hline \multirow[b]{2}{*}{ Fertilizer } & \multirow{2}{*}{$\begin{array}{c}\text { Microbial } \\
\text { material }\end{array}$} & \multirow[b]{2}{*}{ Manure } & \multicolumn{4}{|c|}{ Input amount $\left(\mathrm{kg} \mathrm{ha}^{-1}\right)$} & \multicolumn{3}{|c|}{ Contents (kg ha-1) } \\
\hline & & & Manure & $\begin{array}{l}\text { Chemical } \\
\text { fertilizer } 1 \text { ) }\end{array}$ & $\begin{array}{c}\text { Organic } \\
\text { fertilizer }^{2)}\end{array}$ & $\begin{array}{l}\text { Microbial } \\
\left.\text { material }^{3}\right)\end{array}$ & $\mathrm{N}$ & $\mathrm{P}_{2} \mathrm{O}_{5}$ & $\mathrm{~K}_{2} \mathrm{O}$ \\
\hline Chemical & - & - & - & 2000 & - & - & 160 & 300 & 140 \\
\hline Chemical & - & + & 10,000 & 2000 & - & - & 160 & 300 & 140 \\
\hline Organic & - & - & - & - & 2000 & - & 160 & 300 & 140 \\
\hline Organic & - & + & 10,000 & - & 2000 & - & 160 & 300 & 140 \\
\hline Organic & + & - & - & - & 2000 & 600 & 160 & 300 & 140 \\
\hline Organic & + & + & 10,000 & - & 2000 & 600 & 160 & 300 & 140 \\
\hline
\end{tabular}

Note: 1) Chemical fertilizer was blended at 8,15 , and $7 \%$ of $N, \mathrm{P}_{2} \mathrm{O}_{5}$, and $\mathrm{K}_{2} \mathrm{O}$, respectively.

2) Organic fertilizer was also blended at the same contents as chemical fertilizer.

Table 1. Fertilizer materials and input amount at each plot

\begin{tabular}{lccc}
\hline Material & Total N (\%) & Total C (\%) & C/N ratio \\
\hline Organic fertilizer & 8.0 & 37.5 & 4.7 \\
Microbial material & 2.2 & 14.2 & 65.0 \\
Manure & 1.7 & 21.0 & 12.4 \\
\hline
\end{tabular}

Table 2. Total nitrogen and carbon contents of organic materials

Each plot was $3 \mathrm{~m}$ wide and $6 \mathrm{~m}$ long with 2 replications. The field was harvested soybean in 1993, and tilled by rotary before planting radishes in 1994. Each plot was tilling by deep tiled rotary after appropriate fertilizer and manure application at each crop planting date.

\subsubsection{Radish and potato culture}

Double crop radish (Raphanus sativus L). was planted in the spring (summer radish) and in autumn (autumn radish) of each year. Summer radishes(cv. Taibyou-souhutori) were planted with a plastic mulch on 26, April,1995, 24, April 1996, 18, April 1997. Seeds were planted in a $25 \mathrm{~cm} \times 25 \mathrm{~cm}$ zigzag pattern. The crops were harvested on 22 June ,1995; 25 June 1996 and 18 June 1997. Autumn radishes(cv. Taibyou-souhutori) were planted on 12 September, 1994; 10 September, 1995; 9 September,1996; 10 September,1997. Planting interval was $60 \mathrm{~cm} \times 20 \mathrm{~cm}$. These were harvested on 12 December, 1994; 15 December,1995; 13 December,1996 and 5 December,1997. For each radish culture, insecticide (DDVP) was sprayed for each growing season to prevent cabbage armyworm (Manestra brassicae L.) and common cabbage worm (Pieris rapae crucivora Boisduval).

The plots were divided into two sites after radish harvest in 1996. Potato (cv. Tyoshiro) was planted on 25 March, 1997 with a $72 \mathrm{~cm} \times 25 \mathrm{~cm}$ interval after the same fertilizer treatment 
had been applied. Ridging treatment was applied on 30 April, and harvested on 24 June. No herbicide or insecticide was applied for potato culture.

\subsubsection{Measurement}

Radish yields were measured at each harvest time. A continuous of 20 radishes in a row was taken as a sample at each plot. Each radish was measured for fresh root weight, fresh leaf weight, and root length. At the same time, irregular roots were marked as unmarketable products.

Potato plant length was measured at 30 days after planting and flowering in 1997. Above and potato biomass were determined by sampling 20 continuous potato plants, as potato yields. Potatoes that were over $30 \mathrm{~g}$ were measured as marketable products.

Soil nitrate concentration was measured on 30 Apr, 23 May, and 24 June in 1997during the potato cropping period. Soils were air dried, and extracted with distilled water. Soil nitrate concentrations were measured by nitrate ion analyzer.

Soil samples for determining microbial populations were taken at $10 \mathrm{~cm}$ depth in each plot after the summer radish harvest on $5 \mathrm{Jul}, 1997$ to determine the populations of soil bacteria, fungus, and actinomyces. Microbial population size was determined using the dilution agarplate method. Rose bengal agar media was used for filamentous fungus test. For the bacteria and actinomycetes test, albumin agar media were used for tests.

\subsection{Yield response between different ridging managements for organic fertilizer based potato culture in 2010}

\subsubsection{Field and experimental design}

A field experiment of potato production was conducted at the farmer's farm (latitude $35^{\circ} 56^{\prime} 35^{\prime \prime} \mathrm{N}$, longitude $140^{\circ} 10^{\prime} 36^{\prime \prime} \mathrm{E}$ ) in Ushiku City, Ibaraki prefecture, Japan in clay loam humic allophane soils. Bokashi and chemical fertilizers were applied in potato production. Bokashi was developed in Japan and it uses microorganisms to ferment the waste into nutrients rich compost, was widely applied to increase soil organic matter and improve microbe's activity. Bokashi was made from rice bran, rapeseed meal, rice husk, EM1, sugar and water. The nutrients content of bokashi fertilizer were shown in Table 3.

\begin{tabular}{cccccccccc}
\hline Nutrients & $\begin{array}{c}\mathrm{Ca} \\
(\mathrm{mg} / 100 \mathrm{~g})\end{array}$ & $\begin{array}{c}\mathrm{K} \\
(\mathrm{mg} / 100 \mathrm{~g})\end{array}$ & $\begin{array}{c}\mathrm{Mg} \\
(\mathrm{mg} / 100 \mathrm{~g})\end{array}$ & $\begin{array}{c}\mathrm{NH}_{4}{ }^{-}-\mathrm{N} \\
(\mathrm{mg} / 100 \mathrm{~g})\end{array}$ & $\begin{array}{c}\mathrm{NO}^{-}-\mathrm{N} \\
(\mathrm{mg} / 100 \mathrm{~g})\end{array}$ & $\mathrm{P} \%$ & $\mathrm{C} \%$ & $\mathrm{~N} \%$ & $\mathrm{C} / \mathrm{N}$ \\
\hline Bokashi & 2 & 52 & 7 & 0.8 & 115.6 & $34.6 \%$ & 45.22 & 4.59 & 9.85 \\
\hline
\end{tabular}

Table 3. Nutrients content of Bokashi fertilizer

Potato was planted in a $55 \mathrm{~m} \times 53 \mathrm{~m}$ area, and planting interval was $0.78 \mathrm{~m} \times 55 \mathrm{~m}$. Six $55 \mathrm{~m} \times 0.78 \mathrm{~m}$ plots were laid out, consisting of two treatments with three replications. One treatment was ridged two times+ Inter-tillage (Ridging 3 ) and another treatment was ridged two times (Ridging 2).The shapes of ridging were measured by leica DISTOTM A6, and the data were recorded every $1 \mathrm{~cm}$. The ridging management was different resulting in the different ridging shapes. 


\subsubsection{Potato culture}

Potato was planted in April and harvested in July, 2010. The cropping schedule and farming practice schedule were shown in Table 4 . The total rainfall and mean temperature during potato cropping were $511.5 \mathrm{~mm}$ and $19.3^{\circ} \mathrm{C}$, respectively (Japan Meteorological Agency, 2011).

\begin{tabular}{|c|c|c|c|c|}
\hline Dates & $\begin{array}{c}\text { Farm Work and } \\
\text { Experimental } \\
\text { Contents }\end{array}$ & Materials and Machine & Ridging 3 & Ridging 2 \\
\hline \multirow{5}{*}{$2010 / 2 / 10$} & Fertilizer application & Bokashi 1000kg ha-1-1 & + & + \\
\hline & Subsoiling & $\begin{array}{c}\text { Tractor (60PS) + } \\
\text { Subsoiler }(\mathrm{W} 130 \mathrm{~cm})\end{array}$ & + & + \\
\hline & plow & $\begin{array}{l}\text { Tractor (60PS) + } \\
\text { Plow(depth 25cm) }\end{array}$ & + & + \\
\hline & harrow & $\begin{array}{c}\text { Tractor }(60 \mathrm{PS})+ \\
\text { Harrow }(\mathrm{w} 230 \mathrm{~cm})\end{array}$ & + & + \\
\hline & harrow & $\begin{array}{c}\text { Tractor (28PS) + } \\
\text { Rotary harrow }(\mathrm{w} \\
220 \mathrm{~cm})\end{array}$ & + & + \\
\hline \multirow[t]{2}{*}{$2010 / 2 / 20$} & Seed preparation & $\begin{array}{l}\text { Seed potato (mother } \\
\text { tuber), } 1400 \mathrm{~kg}\end{array}$ & + & + \\
\hline & Fungicide & & + & + \\
\hline $2010 / 3 / 5$ & Planting & $\begin{array}{l}\text { Seed potato (mother } \\
\text { tuber), } 1400 \mathrm{~kg} \\
\text { Planter }\end{array}$ & + & + \\
\hline 2010/3/15 & Inter-tillage & Walking cultivator & + & - \\
\hline \multirow{2}{*}{$2010 / 3 / 25$} & Weeding & $\begin{array}{c}\text { Weeder (Working } \\
\text { type) }\end{array}$ & + & + \\
\hline & Fertilizer application & $\begin{array}{c}\text { NPK (10-16-14) 200kg } \\
\text { Hand spray }\end{array}$ & + & + \\
\hline $2010 / 4 / 10$ & Inter-tillage & $\begin{array}{l}\text { Walking cultivator } \\
\text { (upper type) }\end{array}$ & + & - \\
\hline $2010 / 5 / 5$ & Pesticide spray & Sprayer & + & + \\
\hline \multirow{2}{*}{$2010 / 5 / 10$} & Ridging & $\begin{array}{l}\text { Walking cultivator + } \\
\text { Ridger }\end{array}$ & + & + \\
\hline & Fertilizer application & $\begin{array}{c}\text { PK (0-20-15) 200kg } \\
\text { Hand spray }\end{array}$ & + & + \\
\hline \multirow[b]{2}{*}{$2010 / 5 / 20$} & Pesticide spray & Sprayer & + & + \\
\hline & Ridging & $\begin{array}{c}\text { Walking cultivator }+ \\
\text { Ridger }\end{array}$ & + & + \\
\hline $2010 / 6 / 5$ & Pesticide spray & Sprayer & + & + \\
\hline $2010 / 6 / 20$ & Pesticide spray & Sprayer & + & + \\
\hline $2010 / 7 / 10$ & Harvest & Potato harvester & + & + \\
\hline
\end{tabular}

"+" meant applied, "-“ meant did not apply

Table 4. Cropping schedule and farming system in potato production.

\subsubsection{Measurement}

Potato tuber, root and shoot of potato plant were taken from each experimental plots in flowering season on June 2nd, 2010. Ten continuous potato plant's height was measured in each experimental plot. The fresh weight of potato tuber was measured by electrical balance, 
the shoot and root were oven dry at $60^{\circ} \mathrm{C}$ for 72 hours and weighted to record the biomass. Matured potatoes were harvested on July 8, 2010 to calculate tuber yield and number. To avoid possible edge effects, in each experimental plot the inner ten potato plants were harvested manually as sample plants. Each potato was weighted to calculate starch value $(\%)$ and graded sizes based on the weight to assess appearance quality relevant for marketable value.

Soil samples were taken from topsoil $(0-0.10 \mathrm{~m})$ on: 1) April 13th,2010 after potato planting; 2) April 26, May 17 at vegetative growth stage; 3) June 2, June 18 in flowering season; 4) July 2 and July 8 at tuber maturation stage. Soil samples were collected at each experimental plot. The collected soil samples were air dried, pulverized, ground and sieved to pass $2 \mathrm{~mm}$ mesh before being sent to laboratory for soil nutrients concentration analysis. Soil nutrients analysis of the samples was conducted by SPCA analyzer in FS Center, College of Agriculture, Ibaraki University, Japan.

\section{Results \& discussion}

\subsection{Radish yield responses and related analysis from 1994 to 1997}

Average radish root weights from $1^{\text {st }}$ to $7^{\text {th }}$ harvest is shown in Table 5. At 1st harvest, there were significant differences between fertilizer type and manure input for leaf weight, organic fertilizer and manure plots showing higher leaf weight than the chemical fertilizer and no manure input plots at 1 st harvest. However, there were no significant differences in root weight. At 2nd and 3rd harvests, there were no significant differences between fertilizer system and manure treatment. Following 4th harvest, root growth weight in the organic fertilizer plots was significantly higher than chemical fertilizer plots. For example, across the manure treatments, average roots weight were $964 \mathrm{~g}$ for organic fertilizer, $1010 \mathrm{~g}$ for organic plus microbial material, and $789 \mathrm{~g}$ for chemical fertilizer at 7 th harvest.

There were no significant differences between chemical and organic fertilizer for 1 or 2 years, however, it was clear that the radish growth in the organic fertilizer plots was much higher compared with chemical fertilizer plots 2 or 3 years later. For manure treatment, manure input enhanced leaf growth, but did not show significant effects for root growth.

Noguchi (1992a) reported that organic fertilizer released inorganic nitrogen slower than chemical fertilizer, but it faster than manure. For example, $60-40 \%$ organic nitrogen of organic fertilizer released inorganic nitrogen to 200 days at $30^{\circ} \mathrm{C}$ (Nouguchi, 1992b). So organic fertilizer application over the long term would help to increase soil nutrients. In this research, changes in soil organic matter and nitrogen content were unknown, however, significant crop yield responses may show the difference of soil nutrient contents between organically and chemical fertilizer system.

Average data for 3 years are shown in Table 5. For summer radish culture, the leaf weight was higher in manure plots than no manure input plots, but there was little difference in root length and weight among fertilizer application systems. For autumn radish, the leaf and root weights were higher in organic fertilizer and microbial material plots than in the chemical fertilizer plots. In most cases, root weight decrease in manure plots in each fertilizer application system. However, the effect of microbial materials on radish growth was not clear. 
Soil Management Strategies for Radish and Potato Crops: Yield Response

\begin{tabular}{|c|c|c|c|c|c|c|c|c|c|c|}
\hline \multirow{2}{*}{ Fertilizer } & \multirow{2}{*}{$\begin{array}{l}\text { Micro- } \\
\text { bial } \\
\text { material }\end{array}$} & \multirow{2}{*}{ Manure } & \multicolumn{2}{|c|}{ 1st (autumn) } & \multicolumn{2}{|c|}{ 2nd (summer) } & \multicolumn{2}{|c|}{ 3rd (autumn) } & \multicolumn{2}{|c|}{ 4th (summer) } \\
\hline & & & \begin{tabular}{|c} 
Leaf \\
weight \\
(g/plant)
\end{tabular} & $\begin{array}{c}\text { Root } \\
\text { weight } \\
\text { (g/plant) }\end{array}$ & $\begin{array}{c}\text { Leaf } \\
\text { weight } \\
\text { (g/plant) }\end{array}$ & $\begin{array}{c}\text { Root } \\
\text { weight } \\
\text { (g/plant) }\end{array}$ & $\begin{array}{c}\text { Leaf } \\
\text { weight } \\
\text { (g/plant) }\end{array}$ & $\begin{array}{c}\text { Root } \\
\text { weight } \\
\text { (g/plant) }\end{array}$ & $\begin{array}{c}\text { Leaf } \\
\text { weight } \\
\text { (g/plant) }\end{array}$ & $\begin{array}{c}\text { Root } \\
\text { weight } \\
\text { (g/plant) }\end{array}$ \\
\hline Chemical & - & - & 333.3 & 1155.4 & 578.5 & 912.0 & 378.8 & 876.3 & 384.4 & 767.5 \\
\hline Chemical & - & + & 310.6 & 1046.2 & 620.0 & 939.5 & 399.5 & 949.3 & 425.5 & 716.0 \\
\hline Organic & - & - & 312.6 & 1077.0 & 597.3 & 973.5 & 380.0 & 935.5 & 425.0 & 774.9 \\
\hline Organic & - & + & 403.2 & 1198.7 & 603.3 & 817.5 & 356.8 & 871.0 & 429.0 & 756.9 \\
\hline Organic & + & - & 372.4 & 1231.2 & 597.8 & 836.0 & 393.0 & 1070.3 & 368.8 & 847.4 \\
\hline Organic & + & + & 425.8 & 1118.2 & 579.5 & 784.0 & 363.0 & 880.5 & 493.9 & 886.9 \\
\hline \multicolumn{11}{|c|}{$\begin{array}{l}\text { Significa } \\
\text { nt }\end{array}$} \\
\hline \multicolumn{3}{|c|}{ Fertilizer type } & * & N.S. & N.S. & N.S. & N.S. & N.S. & N.S. & * \\
\hline \multicolumn{3}{|c|}{ Manure } & * & N.S. & N.S. & N.S. & N.S. & N.S. & $*$ & N.S. \\
\hline
\end{tabular}

\begin{tabular}{|c|c|c|c|c|c|c|c|c|}
\hline \multirow{2}{*}{ Fertilizer } & \multirow{2}{*}{$\begin{array}{l}\text { Micro- } \\
\text { bial } \\
\text { material }\end{array}$} & \multirow[b]{2}{*}{ Manure } & \multicolumn{2}{|c|}{ 5th (autumn) } & \multicolumn{2}{|c|}{ 6th (summer) } & \multicolumn{2}{|c|}{ 7th (autumn) } \\
\hline & & & $\begin{array}{c}\text { Leaf } \\
\text { weight } \\
\text { (g/plant) }\end{array}$ & $\begin{array}{c}\text { Root } \\
\text { weight } \\
\text { (g/plant) }\end{array}$ & $\begin{array}{c}\text { Leaf } \\
\text { weight } \\
\text { (g/plant) }\end{array}$ & $\begin{array}{c}\text { Root } \\
\text { weight } \\
\text { (g/plant) }\end{array}$ & $\begin{array}{c}\text { Leaf } \\
\text { weight } \\
\text { (g/plant) }\end{array}$ & $\begin{array}{c}\text { Root } \\
\text { weight } \\
\text { (g/plant) }\end{array}$ \\
\hline Chemical & - & - & 295.0 & 683.2 & 590.2 & 877.9 & 382.3 & 1610.9 \\
\hline Chemical & - & + & 294.2 & 648.4 & 607.3 & 701.7 & 408.2 & 1509.3 \\
\hline Organic & - & - & 307.8 & 805.7 & 661.6 & 956.8 & 414.6 & 1677.9 \\
\hline Organic & - & + & 340.8 & 752.5 & 695.0 & 972.0 & 410.4 & 1537.8 \\
\hline Organic & + & - & 342.7 & 776.6 & 580.4 & 970.0 & 417.4 & 1669.6 \\
\hline Organic & + & + & 332.0 & 685.6 & 726.2 & 1050.9 & 411.2 & 1483.5 \\
\hline \multirow{2}{*}{\multicolumn{3}{|c|}{$\begin{array}{l}\text { Significant } \\
\text { Fertilizer type }\end{array}$}} & & & & & & \\
\hline & & & * & $*$ & * & $*$ & N.S. & N.S. \\
\hline \multicolumn{3}{|c|}{ Manure } & N.S. & N.S. & * & N.S. & N.S. & * \\
\hline
\end{tabular}

Table 5 . The average of radish growth in the relation to fertilizer system (3years)

\begin{tabular}{|c|c|c|c|c|c|c|}
\hline \multirow{2}{*}{ Fertilizer } & \multirow{2}{*}{$\begin{array}{c}\text { Microbial } \\
\text { material }\end{array}$} & \multirow{2}{*}{ Manure } & \multicolumn{3}{|c|}{ Soil microorganism } & \multirow[b]{2}{*}{$\begin{array}{l}\mathrm{B} / \mathrm{F} \text { ratio } \\
\text { /g) }\end{array}$} \\
\hline & & & $\begin{array}{l}\text { Bacteria } \\
\left(\times 10^{7} / \mathrm{g}\right)\end{array}$ & $\left(\times 10^{7} / \mathrm{g}\right)$ & $\left(\times 10^{5} / \mathrm{g}\right)$ & \\
\hline Chemical & - & - & 2.2 & 2.8 & 4.1 & 53.7 \\
\hline Chemical & - & + & 3.9 & 2.1 & 2.8 & 139.3 \\
\hline Organic & - & - & 2.4 & 3.3 & 2.9 & 82.8 \\
\hline Organic & - & + & 4.9 & 3.2 & 2.7 & 181.5 \\
\hline Organic & + & - & 3.3 & 2.8 & 2.4 & 137.5 \\
\hline Organic & + & + & 5.5 & 3.8 & 3.5 & 157.0 \\
\hline
\end{tabular}

Table 6. Soil microorganism population in the relation to different fertilizer system

The populations of soil microorganisms in the $6^{\text {th }}$ radish culture were shown in Table 6 . Manure input plots showed higher bacteria population than no manure input plots, but differences among fertilizer types was not clear. The populations of actinomyces and fungus were also not affected by treatment; however, the $\mathrm{B} / \mathrm{F}$ value was high in the organic fertilizer plots manure input plots. 
$\mathrm{B} / \mathrm{F}$ value is one of the most important indicators for evaluating soil microorganism condition. Usually, high B/F values show healthier soil conditions than lower values (Kato et al, 1977). In this research, the population of soil microorganism was less than in farmer's fields, because this field had not been manured for many years. However, it was notable that organic fertilizer and manure input could improve soil microorganism conditions. These soil biological condition might enhance the radish growth.

\subsection{Potato yield respond and related analysis in 1997}

Potato growth and yields were shown in Table 7. At flowering season, above and underground biomass were higher in organic fertilizer plots than in chemical fertilizer plots irrespective of microbial materials application. While manure application was also effective in increasing above ground biomass yields in any fertilizer treatment, however, underground biomass decreased in manure plots. Potato yields were highest in organic fertilizer with manure application plots, followed by organic fertilizer with microbial materials and manure application plots.

Yano et al (1982) reported input of organic fertilizer improved potato yields significantly, in this research, manure input treatment showed high yields compared with no manure input plots. However, it is noteworthy that organic fertilizer also improved potato yields.

\begin{tabular}{|c|c|c|c|c|c|c|c|}
\hline \multirow{2}{*}{ Fertilizer } & \multirow{2}{*}{$\begin{array}{l}\text { Microbial } \\
\text { material }\end{array}$} & \multirow{2}{*}{ Manure } & \multicolumn{4}{|c|}{ Flowering time (6 Jun) } & \multirow{2}{*}{$\begin{array}{c}\text { Yield } \\
\text { (g/plant) }\end{array}$} \\
\hline & & & $\begin{array}{l}\text { Above ground biomass } \\
(\mathrm{g} / \text { plant })\end{array}$ & $\begin{array}{l}\text { Potato biomas } \\
\text { (g/plant) }\end{array}$ & $\mathrm{T} / \mathrm{R}$ ratic & $\begin{array}{l}\text { Dry weight } \\
\text { (g/plant) }\end{array}$ & \\
\hline Chemical & - & - & 293.8 & 319.7 & 0.91 & 30.8 & 558 \\
\hline Chemical & - & + & 451.2 & 304.1 & 1.83 & 41.7 & 770 \\
\hline Organic & - & - & 353.5 & 482.3 & 0.74 & 38.5 & 822 \\
\hline Organic & - & + & 458.4 & 282.5 & 1.71 & 39.8 & 945 \\
\hline Organic & + & - & 518.3 & 568.4 & 0.91 & 54.1 & 706 \\
\hline Organic & + & + & 848.3 & 583.2 & 1.46 & 76.9 & 869 \\
\hline \multicolumn{3}{|c|}{ Significant } & * & $\stackrel{*}{*}$ & $\begin{array}{c}\text { N.S. } \\
*\end{array}$ & N.S & * \\
\hline \multicolumn{3}{|l|}{ Manure } & N.S. & N.S. & * & N.S. & * \\
\hline
\end{tabular}

* and NS indicated significance at $5 \%$ and not significant.

Table 7. Potato growth and yields in the relation to different fertilizer system

\begin{tabular}{lcc|ccc}
\hline \multirow{2}{*}{ Fertilizer } & $\begin{array}{c}\text { Microbial } \\
\text { material }\end{array}$ & Manure & \multicolumn{3}{|c}{ Soil Nitarate (mg/100g dry soil) } \\
& 30 Apr. & 23 May & 24 Jun \\
\hline Chemical & - & - & 48.0 & 15.6 & 3.3 \\
Chemical & - & + & 81.0 & 21.3 & 3.6 \\
Organic & - & - & 12.3 & 12.3 & 2.7 \\
Organic & - & + & 51.0 & 14.7 & 3.0 \\
Organic & + & - & 60.0 & 11.4 & 3.9 \\
Organic & + & + & 135.0 & 10.8 & 4.2 \\
\hline
\end{tabular}

Table 8 . Nitrate concentration in the relation to different fertilizer system 
The changing of soil nitrate concentration in potato culture in 1997 was shown in Table 8 . On 30 April, organic fertilizer with microbial material plots showed the highest nitrate concentration, followed by chemical fertilizer plots, while organic fertilizer without microbial materials plots were lowest. Manure plots showed higher nitrate concentrations than no manure input plots. On 23 May, it was highest in chemical fertilizer plots, followed by organic fertilizer without microbial materials, while organic fertilizer with microbial materials plots were the lowest. However, these differences disappeared on 24 June. Microbial materials application enhanced nitrate release from organic fertilizer at the early stage of growth.

\subsection{Economic productivity}

The economic productivities between chemical and organic fertilizers for radish and potato culture from 1994 to 1997 were shown in Table 9. For no manure input plots, the cost of summer radish culture increased by $15 \%$ for organic fertilizer, and $29 \%$ for organic fertilizer plus microorganism material compared with chemical fertilizer plots, so the cost per food weight also increased by $5 \%$ and $16 \%$, respectively. The cost of autumn radish culture also increased $12 \%$ and $24 \%$, respectively, however, so the cost per food weight decreased $4.3 \%$ for organic fertilizer plots, in spite of that increased $9 \%$ for the organic fertilizer plus microbial materials plot. In addition, the cost of potato culture increased $46 \%$ for organic fertilizer, and $74 \%$ for organic fertilizer plus microbial material compare with chemical fertilizer plots, however, so the cost per food weight decreased $5.4 \%$ for organic fertilizer plots , in spite of that increased $37.8 \%$ for organic fertilizer plus microbial materials plot.

For manure input plots, chemical fertilizer plots showed the lowest cost per food weight for summer radish, autumn radish and potato. For radish culture, manure input could not decrease the cost of food weight, but it did help to increase potato yields significantly.

These results suggested that the economic benefit of using organic fertilizer, microbial material, and manure differed depending on the crops. Organic fertilizer showed good performance for radish culture, while, chemical fertilizer plus manure input showed good performance for potato culture. In this research, the benefit of using microbial material was not clear, so, for the present results, microbial material may have some potential to improve crop yields, but their cost may hinder their use in crop production.

Organic fertilizer could be one of the most important materials to establish sustainable agriculture system. They can add organic matter in the soil and improve soil quality. In addition, to use organic fertilizer has more benefit for our society, because it can contribute to establish Recycle-Based Society. In this research, it was clear that organic fertilizer can improve radish and potato yields on a long term basis. However, another strategy to reduce the increasing cost to use organic fertilizer is needed.

\subsection{Potato yield respond and related analysis in $\mathbf{2 0 1 0}$}

Soil fertility and crop quality could be improved by proper farming practices. Potatoes were planted in 2010, which including two different ridging managements. Soil properties and potato quality was observed in this study. The ridging heights were different because of different riding managements (Figure 1), which influenced the soil properties and thus influenced potato yield to some extent. 


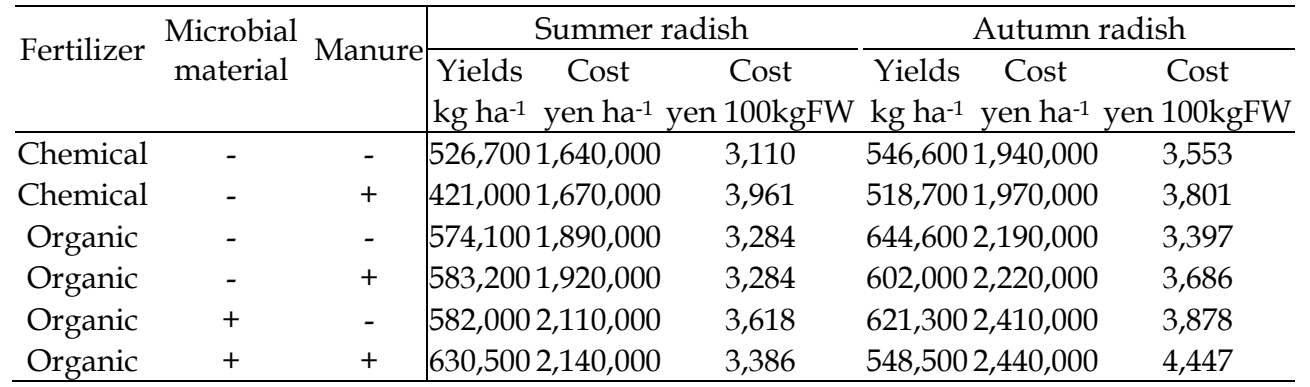

\begin{tabular}{lcc|ccc}
\hline \multirow{2}{*}{ Fertilizer } & \multirow{2}{*}{ Microbial material } & \multirow{2}{*}{ Manure } & \multicolumn{3}{|c}{ Potato } \\
\cline { 4 - 6 } & & & $\begin{array}{c}\text { Yields } \\
\mathrm{kg} \mathrm{ha}^{-1}\end{array}$ & $\begin{array}{c}\text { Cost } \\
\text { yen ha- }\end{array}$ & $\begin{array}{c}\text { Cost } \\
\text { yen 100kgFW }\end{array}$ \\
\hline Chemical & - & - & 306,900 & 630,000 & 2,049 \\
Chemical & - & + & 423,500 & 660,000 & 1,555 \\
Organic & - & - & 452,100 & 880,000 & 1,939 \\
Organic & - & + & 519,800 & 910,000 & 1,748 \\
Organic & + & - & 388,300 & $1,100,000$ & 2,824 \\
Organic & + & + & 478,000 & $1,130,000$ & 2,356 \\
\hline
\end{tabular}

1) Seed, chemicals materials without fertilizer, power sources, machines, and labor costs were quated by vegetable production cost survey (MAFF, 1997).

2) The yields of summer and autumn radish were used in 6th and 5th culture. 2) The yields of summer and autumn radish were used in 6th and 5th culture.

Table 9. Economically productively in relation to different fertilizer system

Soil temperature was recorded every 30 minutes in the whole period of potato production in 2010. The results showed that soil average temperatures of Ridging 3 were $19.5^{\circ} \mathrm{C}$ and $19^{\circ} \mathrm{C}$ at $3 \mathrm{~cm}$ and $10 \mathrm{~cm}$ depth, and Ridging 2 were $18.8^{\circ} \mathrm{C}$ and $18.7^{\circ} \mathrm{C}$, respectively (Figure 2). The highest soil temperature under Ridging 3 was $46.8^{\circ} \mathrm{C}$ at $3 \mathrm{~cm}$ soil depth, and the highest soil temperature under Ridging 2 was $36.4^{\circ} \mathrm{C}$ at $3 \mathrm{~cm}$ soil depth. The lowest temperature was $2.2^{\circ} \mathrm{C}$ under Ridging 3 and $2.0^{\circ} \mathrm{C}$ under Ridging 2 at $3 \mathrm{~cm}$ soil depth, respectively. The change of temperature of Ridging 3 treatment was more remarkable than Ridging 2 treatment.
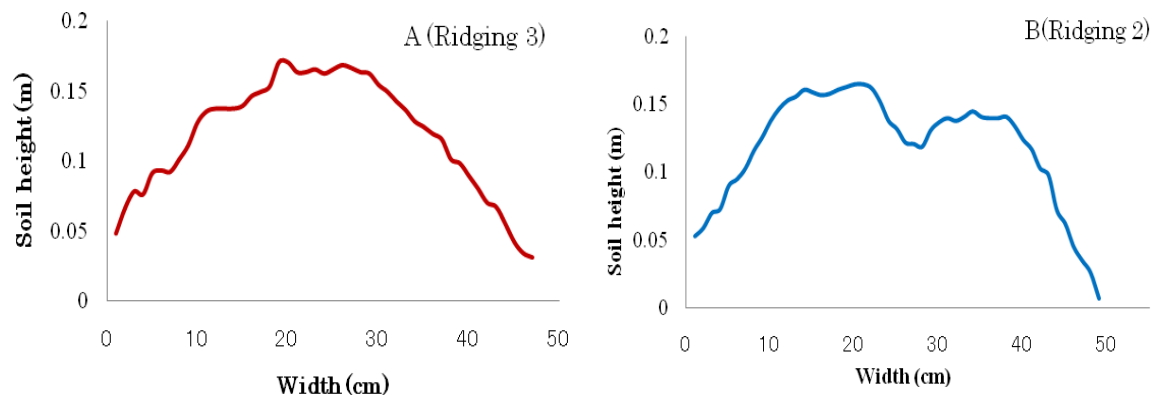

Fig. 1. The shapes of riding managements in potato production (2010). The ridging shapes of the two managements were measure on June 18, 2010. 


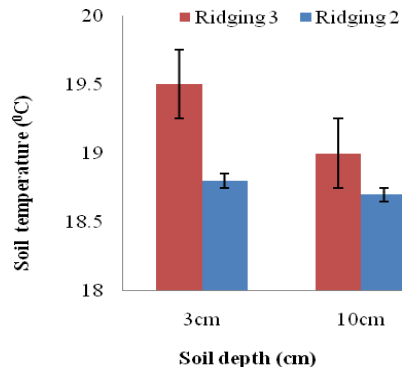

Fig. 2. Soil average temperatures in potato production (2010)

The effect of different ridging managements on soil $\mathrm{PH}$ and soil EC was insignificant, but the effect of dates on soil PH and soil EC was significant (Table 10). Though different ridging managements did not have any significant effect on soil $\mathrm{PH}$ and soil $\mathrm{EC}$, but most soil $\mathrm{PH}$ and soil EC observed from Ridging 3 were higher than Ridging 2 in potato production. The effect of different ridging managements on soil nutrients concentrations was insignificant but the dates had remarkably significant effect on soil nutrients concentrations. Figure 3 show the soil nutrients concentrations in the potato production.

Table 11 and Table 12 showed the potato yields and characters in 2010. In flowering season, results showed that the effect of different ridging managements on potato root weights was significant, Ridging 3 promoted significantly the root growth than Ridging 2 . Though different ridging managements did not have any significant effect on aboveground biomass, Ridging 3 produced the higher aboveground biomass than Ridging 2 . The effect of different ridging managements on crop heights was insignificant and crop heights under the two managements were similar. The effect of different ridging managements on potato yield and number per plant in flowering season was insignificant and Ridging 3 produced a lower yield and number per plant than Ridging 2.

\begin{tabular}{ccccccccc}
\hline Factor & $\mathrm{PH}$ & $\mathrm{EC}$ & $\mathrm{Ca}$ & $\mathrm{K}$ & $\mathrm{Mg}$ & $\mathrm{NH}_{4}{ }^{+}-\mathrm{N}$ & $\mathrm{NO}_{3}-\mathrm{N}$ & $\mathrm{P}$ \\
\hline Treatment & $\mathrm{NS}$ & $\mathrm{NS}$ & $\mathrm{NS}$ & $\mathrm{NS}$ & $\mathrm{NS}$ & $\mathrm{NS}$ & $\mathrm{NS}$ & $\mathrm{NS}$ \\
Date & $* * *$ & $* * *$ & $* * *$ & $*$ & $* *$ & $* * *$ & $*$ & $*$ \\
Treatment $\times$ Date & $\mathrm{NS}$ & $\mathrm{NS}$ & $\mathrm{NS}$ & $\mathrm{NS}$ & $\mathrm{NS}$ & $\mathrm{NS}$ & $\mathrm{NS}$ & $\mathrm{NS}$ \\
$*, * *, * * *$ \\
meant $5 \%, 1 \%, 0.1 \%$ & significant each symbol. And NS meant not significant. \\
\hline
\end{tabular}

Table 10. ANOVA of soil properties in potato production (2010)

At harvest stage, results showed that the effect of different ridging managements on yields and numbers of potato and marketable potato and potato per plant was insignificant. The yields obtained from Ridging 3 were lower than Ridging 2 for potato and marketable potato, however, the numbers obtained from Ridging 3 were higher than Ridging 2 for potato and marketable potato. The effect of different ridging managements on yields and numbers of potato and marketable potato was reversing. Ridging 3 produced a little bit lower potato yield per plant than Ridging 2 at harvest stage that was same as the results observed in flowering season, but the potato number per plant obtained from Ridging 3 was higher than Ridging 2 at harvest stage. 

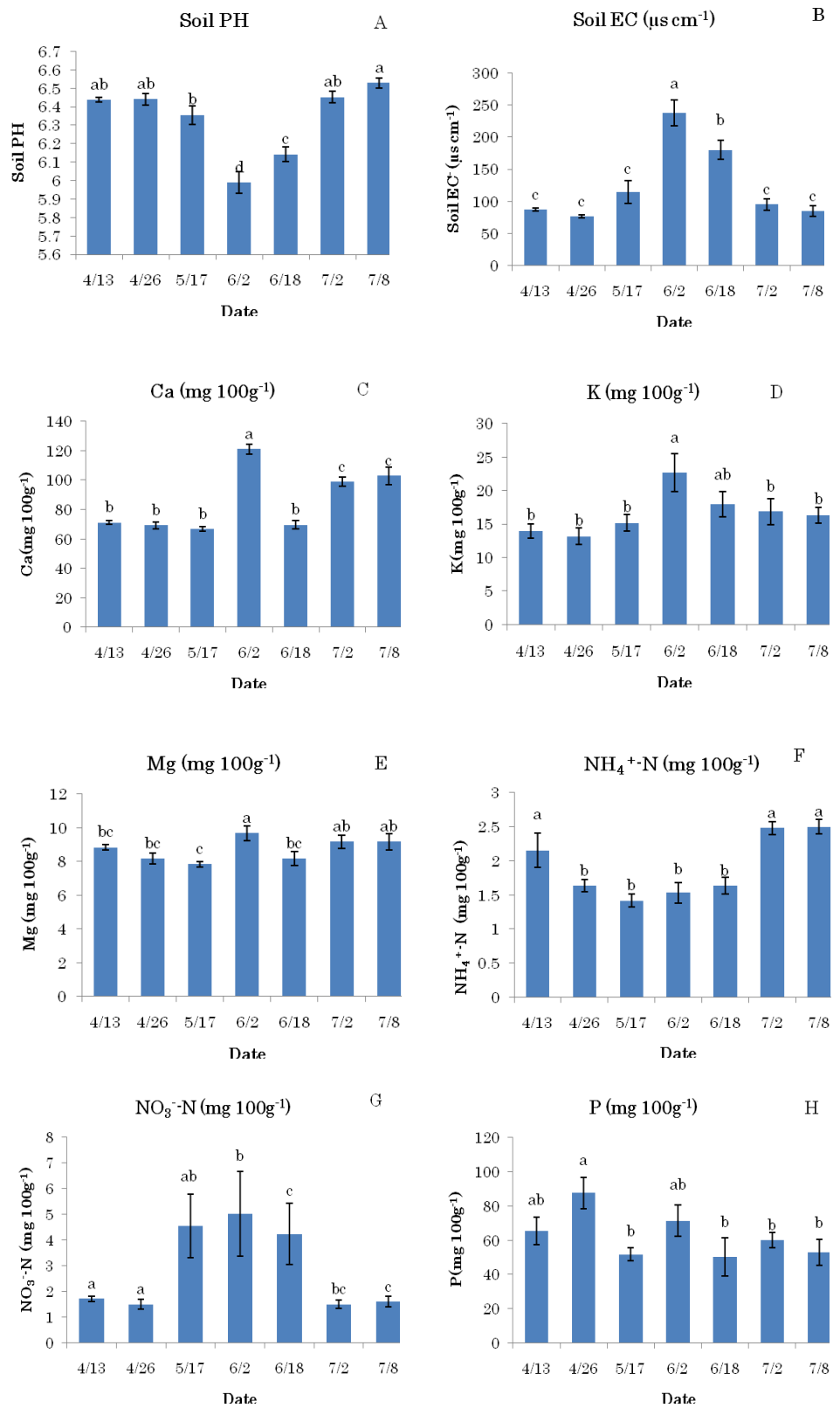

Fig. 3. Soil nutrients concentrations in potato production (2010). The effect of dates on soil $\mathrm{PH}$, soil EC, soil Calcium, Potassium, Magnesium, $\mathrm{NH}_{4}{ }^{+}-\mathrm{N}, \mathrm{NO}_{3}^{-}-\mathrm{N}$, and Phosphorus concentrations were significant. The alphabets indicated the difference between different dates $(\mathrm{P} \leqq 0.05 \%)$. 
Ridging 3 had the higher root weight of potato, but produced lower yield of potato, which may be explained that the soil temperatures were different under different ridging managements. The proper temperature of potato tuber growth is $20^{\circ} \mathrm{C}$, and tuber growth stops if the temperature is over $30^{\circ} \mathrm{C}$. Ridging 3 had higher soil temperatures, which promote the aboveground stem and leaf growth by photosynthesis, however, leading to less photosynthesis for tuber growth, so Ridging 3 had higher aboveground biomass than Riding 2 but produced lower yield of potato than Ridging 2 . The number of potato increased and the weight of potato decreased if the soil temperatures were higher, so Ridging 3 produced higher potato number and lower average weight of potato than Riding 2.
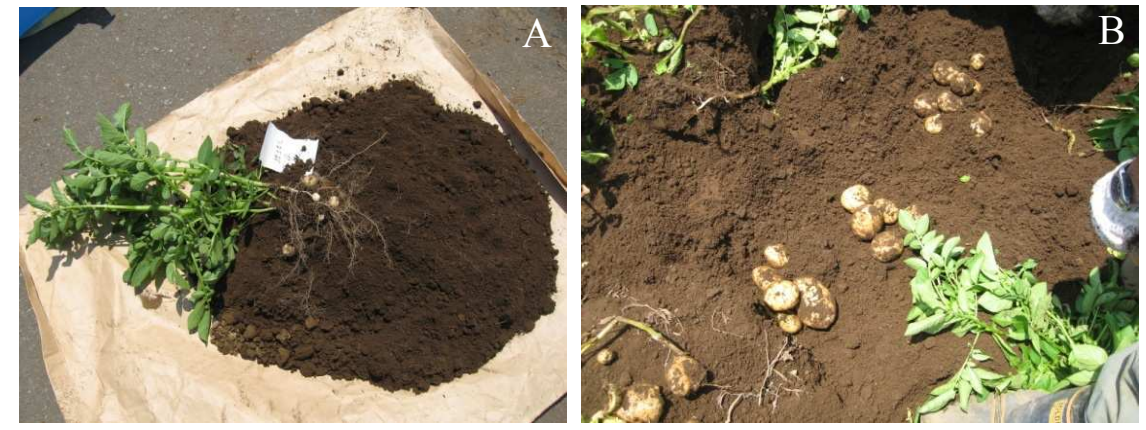

Plate 1. Photos of potato production field in Ushiku City, Ibaraki Prefecture,Japan. In the flowering season, potato roots and shoots was collected (Photo A). In harvest stage, continuous ten plants was harvested mannually for potato yield and quality analysis (Photo B).

In this study, potato grade based on starch values was served as the evaluation factor. The starch values of high grade potatoes focused on 12\%-19\% (Yoshida, 1988). Average starch values and the percentages of high grade potatoes under two managements were shown in Table 13. Results showed that the effect of different ridging managements on potato starch values was significant. Ridging 2 produced higher average starch value, Ridging 3 produced more high grade potatoes. $87.7 \%$ potatoes obtained from Ridging 3 were high grade potatoes; however, $84.5 \%$ potatoes obtained from Ridging 2 were high grade potatoes. That suggested that Ridging 3 had positive effect on table potato production industry. There were $12.6 \%$ potatoes produced from Ridging 3 that starch values were less than $12 \%$, however, there were $14.4 \%$ potatoes produced from Ridging 2 that starch values were less than $12 \%$. $1.2 \%$ potatoes produced from Ridging 2 that starch values were over $19 \%$ and no potatoes produced from Ridging 3 that starch values were over 19\% (Figure 4).

The weight of matured potato was served as the standard of evaluating appearance quality of potato in this research. Results showed that the effect of different ridging managements on potato weights was significant but on marketable potato weights was insignificant (Table 13). The average weight of potato obtained from Ridging 3 was lower than Ridging 2 . The weight of marketable potato obtained from Ridging 3 was also lower than Ridging 2. Ridging 2 had positive effect on the weights of potatoes and marketable potatoes. $21.1 \%$ and $43.4 \%$ potatoes produced from Ridging 3 were S and M sizes, respectively, and $19.8 \%$ and $37.7 \%$ potatoes produced from Ridging 2 were S and M sizes, respectively. Moreover, $24.0 \%$ and $2.3 \%$ potatoes produced from Ridging 3 were L and $2 \mathrm{~L}$ sizes, and $30.5 \%$ and $8.4 \%$ potatoes produced from Ridging 2 were L and 2L sizes (Figure 5). 


\begin{tabular}{cccccc}
\hline Treatment & $\begin{array}{c}\text { Crop height } \\
(\mathrm{cm})\end{array}$ & $\begin{array}{c}\text { Aboveground } \\
\text { biomass } \\
\left(\mathrm{g} \mathrm{plant}^{-1}\right)\end{array}$ & $\begin{array}{c}\text { Root } \\
\text { weight } \\
\left(\mathrm{g} \mathrm{plant}^{-1}\right)\end{array}$ & $\begin{array}{c}\text { Potato yield } \\
\left(\mathrm{g} \mathrm{plant}^{-1}\right)\end{array}$ & $\begin{array}{c}\text { Potato } \\
\text { number } \\
\left(\text { plant }^{-1}\right)\end{array}$ \\
\hline Ridging 3 & 45.6 & 24.3 & 13.8 & 112.8 & 4.7 \\
Ridging 2 & 46.7 & 18.7 & 5.0 & 118.5 & 5.3 \\
Significant & & & & NS & NS \\
Treatment & NS & NS & $*$ & NS & \\
\hline
\end{tabular}

Table 11. Potato growth and yields in flowering season

\begin{tabular}{lcccccc}
\hline Treatment & \multicolumn{7}{c}{ Yarvest stage (July 8, 2010) } \\
& $\begin{array}{c}\text { Yield } \\
\left(\text { g plant }^{-1}\right)\end{array}$ & $\begin{array}{c}\text { Number } \\
\left(\text { plant }^{-1}\right)\end{array}$ & $\begin{array}{c}\text { Yield } \\
\left(\mathrm{t} \mathrm{ha}^{-1}\right)\end{array}$ & $\begin{array}{c}\text { Number } \\
\left(000 \mathrm{ha}^{-1}\right)\end{array}$ & $\begin{array}{c}\text { Marketable } \\
\text { Yield } \\
\left(\mathrm{t} \mathrm{ha}^{-1}\right)\end{array}$ & $\begin{array}{c}\text { Marketable } \\
\text { Number } \\
\left(000 \text { ha }^{-1}\right)\end{array}$ \\
\hline Ridging 3 & 590.7 & 5.8 & 31.4 & 308.7 & 31.0 & 289.4 \\
Ridging 2 & 635.5 & 5.6 & 33.5 & 293.4 & 32.9 & 284.5 \\
Treatment & NS & NS & NS & NS & NS & NS \\
\hline
\end{tabular}

Table 12. Potato growth and yields at harvest time

\begin{tabular}{lccccc}
\hline Treatment & $\begin{array}{c}\text { Average } \\
\text { weight of } \\
\text { marketable } \\
\text { potato }(\mathrm{g})\end{array}$ & $\begin{array}{c}\text { Average } \\
\text { weight of } \\
\text { potato }(\mathrm{g})\end{array}$ & $\begin{array}{c}\text { Average } \\
\text { Starch value } \\
\text { of potato }(\%)\end{array}$ & $\begin{array}{c}\text { High } \\
\text { grade } \\
\text { potatoes } \\
(\%)\end{array}$ & $\begin{array}{c}\text { Marketable } \\
\text { and high } \\
\text { grade } \\
\text { potatoes (\%) }\end{array}$ \\
\hline Ridging 3 & 107.7 & 101.3 & 13.3 & 87.7 & 84.6 \\
Ridging 2 & 115.1 & 114.2 & 13.8 & 84.5 & 82.6 \\
& NS & Significant & & * \\
Treatment & NS & NS & \\
${ }^{*}$ meant 5\% significant symbol. And NS meant not significant.
\end{tabular}

Table 13. Potato quality in 2010 

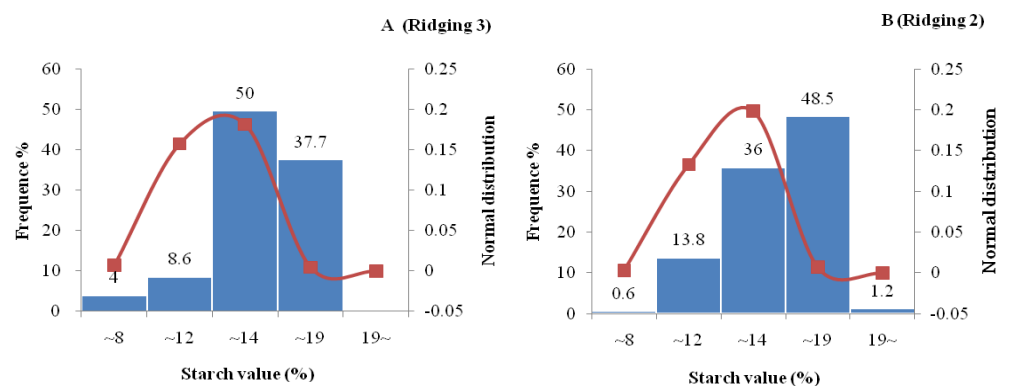

Fig. 4. Histogram and normal distribution of starch values of potatoes (2010). Most starch values obtained from Ridging 3 focused on 13\% 14\% (A), most starch values obtained from Ridging 2 focused on 15\% 19\% (B).

The starch values of high grade potatoes were in the range of $12 \% \sim 19 \%$, and the weights of potatoes were over $30 \mathrm{~g}$ recording as marketable potatoes. The marketable and high grade potatoes were the potatoes that starch values and weights met above two conditions. The percentage of marketable and high grade potatoes produced from Ridging 3 was $84.6 \%$ and that produced from Ridging 2 was $82.6 \%$ (Table 13 ). Ridging 3 produced more marketable and high grade potatoes than Ridging 2. The relationships between starch values and weights of marketable and high grade potatoes were shown in Figure 6.
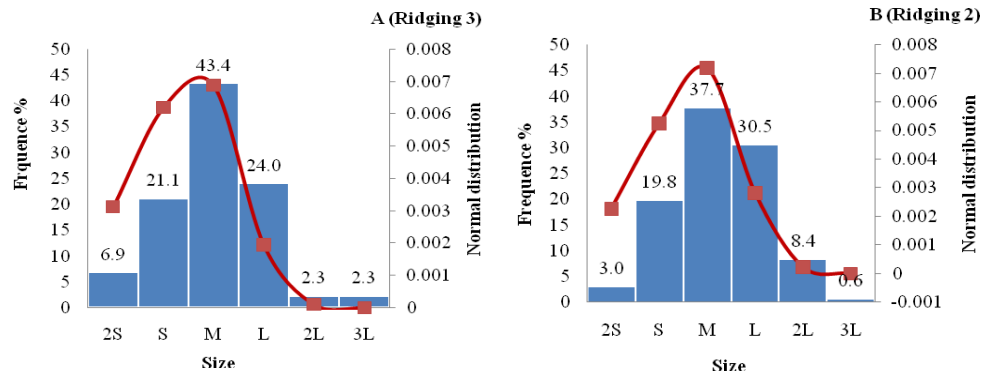

Fig. 5. Histogram and normal distribution of weights of potatoes (2010). Ridging 3 had positive effect on $S$ and $M$ sizes potatoes (A), and Ridging 2 had positive effect on $\mathrm{L}$ and $2 \mathrm{~L}$ sizes potatoes (B).

These results suggested that the 3 time ridging promote the appropriate shape of the ridge that enhances the soil temperature in the ridge. These effects also enhance the roots distribution in the ridge, and improve the ratio of high grade potato compare with 2 time ridging. These differences may be influenced by differences decompose speed of organic fertilizer Bochashi between 2 and 3 time ridging treatments.

\subsection{Conclusion}

Chemical fertilizers consumption in agriculture sector reached 5 times level of 1975 in 1990 and increased slightly afterwards in Japan. In Asian countries, since Jump in crude oil prices in $21^{\text {st }}$ century, as increase chemical fertilizer price due to increasing oil prices, most farmer 
A (Ridging 3)

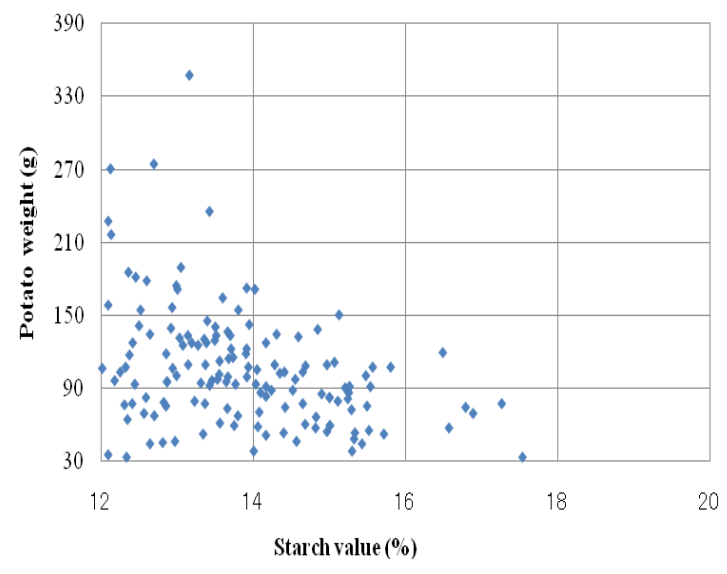

B (Ridging 2)

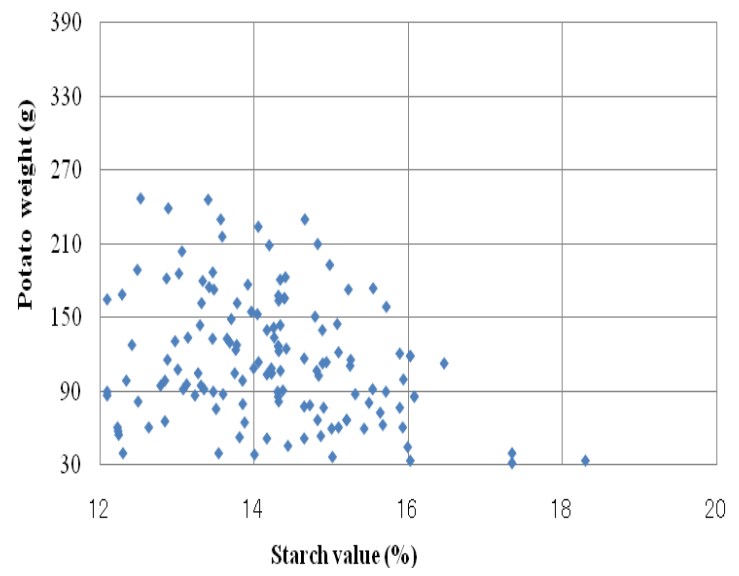

Fig. 6. The relationships between starch values and weights of marketable and high grade potatoes (2010).

favorable to use organic fertilizer. Bocashi is the traditional way to make compost using agricultural sub products and waste in Japan, and this technique is widely spared to the other Asian countries. In this chapter, we discussed the benefits of organic fertilizer for radish and potato production.

There were no significant difference between chemical and organic systems for 1 or 2 years, however, it 1 was clear that the radish growth in organic fertilizer plots was higher than in chemical fertilizer plots 2 or 3 years later. Potato yields were highest in organic fertilizer with manure application plots, followed by organic fertilizer with bacteria materials and 
manure application plots. The lowest value was in unmanured chemical fertilizer plots. Manured plots showed higher bacteria populations than unmanured plots, however, difference among fertilizer types were not clear. The populations of actinomyces and fungus were also not affected treatment, however, the B/F value was high in the organic fertilizer plots and manured plots. While organic fertilizer showed good performance for radish culture, chemical fertilizer plus manured showed good performance for potato culture. The benefit of using microbial material was not clear, so, for the present results, microbial material may have some potential to improve crop yields, but their cost may hinder their use in crop production.

The use of bocashi organic fertilizer as alternative soil fertility amendments in nutrients effective to eliminate the chemical fertilizer, enhance the sub materials from rice production.

We also discussed the appropriate farming practice based organic fertilizer application management for potato production in farmer's field. The results suggested that 3 time ridging promote the appropriate shape of the ridge that enhances the soil temperature in the ridge. These effects also enhance the roots distribution in the ridge, and improve the ratio of high grade potato compare with 2 time ridging. These differences may be influenced by differences decompose speed of organic fertilizer Bocashi between 2 and 3 time ridging treatments. These results would contribute the development for conservation farming system for eliminating the use of chemical fertilizer.

\section{Acknowledgment}

We appreciate Iseki Kanto Co. Ltd. for their kind assistance to supply the experimental materials. We appreciate Mr. Motomu Takamatsu and Mr. Shingo Abe for their technical assistance to provide the field experiment. This work was supported by Grant-in-Aid for Scientific Research (C) (22580286).

\section{References}

Brian Baker, Sean L. Swezey ,David Granatstein, Steve Guldan, David Chaney (2005). Organic Farming Compliance Handbook: A Resource Guide for Western Region Agricultural Professionals, Western Region USDA SARE program. P 1-3.

Carter, M. R., Holmstrom, D., Sanderson, J. B., Ivany, J. and DeHaan, R. (2005) Comparison of conservation with conventional tillage for potato production in Atlantic Canada: crop productivity, soil physical properties and weed control. Can. J.Soil Sci. 85: 453461.

Jongtae Lee (2010). Effect of application methods of organic fertilizer on growth, soil chemical properties and microbial densities in organic bulb onion production. Scientia Horticulturae, 124, 299-305.

Matsumoto, M (1983) roots growth, Nogyogizyutu taikei, Vegetable 9, radish, carrot and turnip,23-40, Noubunkyo, Tokyo.

Noguchi, K., (1992a) Organic fertilizer and soil micro livings 1, Nogyo oyobi Engei. 67:673677.

Noguchi, K., (1992b) Organic fertilizer and soil micro livings 3, Nogyo oyobi Engei. 67:883887. 
Kato, K., E. Kokawa, S. Tsuru, and T. Suzuki (1977) Bacteria-Fungi ratio in several soils, Journal of the science of soil and manure, Japan, 48(9,10):437-438.

Yoshida(1988). Encyclopedia of Potato. Rural Culture Association Japan. P 77. 


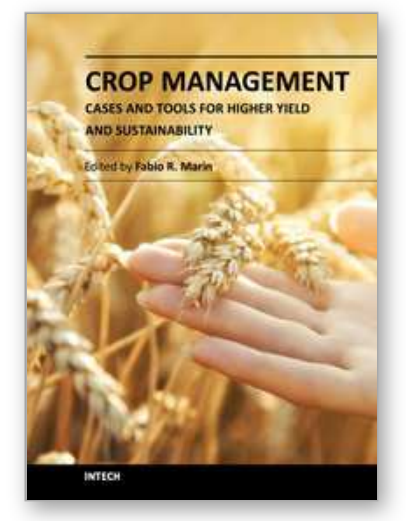

\author{
Crop Management - Cases and Tools for Higher Yield and \\ Sustainability \\ Edited by Dr. Fabio Marin
}

ISBN 978-953-51-0068-3

Hard cover, 118 pages

Publisher InTech

Published online 22, February, 2012

Published in print edition February, 2012

Agricultural production is related to physical constrains, which may not always be overcomed by technology. However, under the same conditions, it is possible to see well-managed farms consistently making greater profits than similarly structured, neighboring farms. For each abiotical condition, it is well-known there is a difference between the potential and observed yields, which is usually high and often could be reduced through more appropriate management techniques. In this book, we have a selection of agricultural problems encountered in different regions of the world which were addressed using creative solution, offering new approaches for well-known techniques and new tools for old problems.

\title{
How to reference
}

In order to correctly reference this scholarly work, feel free to copy and paste the following:

Masakazu Komatsuzaki and Lei Dou (2012). Soil Management Strategies for Radish and Potato Crops: Yield Response and Economical Productivity in the Relation to Organic Fertilizer and Ridging Practice, Crop Management - Cases and Tools for Higher Yield and Sustainability, Dr. Fabio Marin (Ed.), ISBN: 978-953-510068-3, InTech, Available from: http://www.intechopen.com/books/crop-management-cases-and-tools-forhigher-yield-and-sustainability/soil-management-strategies-for-radish-and-potato-crops-yield-response-andeconomical-productivity-in

\section{INTECH}

open science | open minds

\author{
InTech Europe \\ University Campus STeP Ri \\ Slavka Krautzeka 83/A \\ 51000 Rijeka, Croatia \\ Phone: +385 (51) 770447 \\ Fax: +385 (51) 686166 \\ www.intechopen.com
}

\author{
InTech China \\ Unit 405, Office Block, Hotel Equatorial Shanghai \\ No.65, Yan An Road (West), Shanghai, 200040, China \\ 中国上海市延安西路65号上海国际贵都大饭店办公楼405单元 \\ Phone: +86-21-62489820 \\ Fax: +86-21-62489821
}


(C) 2012 The Author(s). Licensee IntechOpen. This is an open access article distributed under the terms of the Creative Commons Attribution 3.0 License, which permits unrestricted use, distribution, and reproduction in any medium, provided the original work is properly cited. 